UDC 34(497.5):929 Bodiroga Vukobrat N.

DOI: https://doi.org/10.22598/iele.2019.6.1.1

\title{
IN MEMORIAM: PROFESSOR NADA BODIROGA VUKOBRAT, PhD
}

\section{Kristijan Poljanec *}

Prof. Nada Bodiroga Vukobrat, $\mathrm{PhD}$ was one of the leading figures of the Croatian academic community, who left a profound trace in the field of European Union Law, Social Security Law, Labor Law, Corporate Social Responsibility, Healthcare Law, Personalized Medicine and Free Provision of Services Law. Her professional and human horizons were remarkably broad, reflecting her working energy, proactivity, and enormous enthusiasm.

Prof. Bodiroga Vukobrat, PhD was born on October 5, 1959, in Mostar, Bosnia and Herzegovina. She graduated from the Faculty of Law, University of Mostar and received her master and doctoral degree at the Faculty of Law, University of Belgrade. During her career, she visited and cooperated with leading European institutes such as Max-Planck-Institut für ausländisches und internationales Sozialrecht in Munich, European University Institute in Florence, University of Vienna and Catholic University in Leuven.

With the outbreak of war in Bosnia and Herzegovina, she left for Germany, and spent those turbulent times in a dedicated work at the University of Mainz and Max-Planck-Institut für ausländisches und internationales Sozialrecht. With those two institutions, she continued to nourish close ties ever since. Finally, in 1997 she joined the Faculty of Law, University of Rijeka, where she spent the following two decades in active scholarly and pedagogical work. She brought up generations of students and young researchers as professor of EU Public Law, EU Labour and Social Law, Head of Department of EU Public Law, Director of the Jean Monnet Inter-University Center of Excellence, Opatija and Co-Director of the Postgraduate Studies in EU Integrations Law. Besides her teaching and academic activity, Prof. Bodiroga Vukobrat held the post of Vice-Dean for International Cooperation at the Faculty of Law University of

* Teaching and Research Assistant, Law Department, Faculty of Economics and Business, University of Zagreb; kpoljanec@efzg.hr 
Rijeka and served as editor of the series 'Europeanization and Globalization', published by Springer.

Prof. Bodiroga Vukobrat also took an active part in various domestic and international research projects, focusing on issues of social security, social and workers' rights across Europe. She engaged actively in the organization of domestic and international conferences and meetings dedicated to issues of social security, labor and healthcare law.

Although she spent most of her academic career in Rijeka, Prof. Bodiroga Vukobrat, $\mathrm{PhD}$ stayed closely related to her alma mater - University of Mostar - and was eager to integrate it into a broader European academic community.

For her credits in research, pedagogical and public work she received the University of Rijeka Foundation Prize in 2009. For her contribution to the Croatian legal science, she was awarded posthumously with "Dr. Jadranko Crnić Award" for 2019.

Last but not least: Prof. Bodiroga Vukobrat, PhD served as a member of the Editorial Board of the InterEULawEast Journal for International and European Law, Economics and Market Integrations. On this occasion, we would like to express our deep gratitude for valuable comments she made and the supportive role she took in the process of realization of the idea to start a new journal.

Prof. Bodiroga Vukobrat, PhD passed away on March 21, 2019. 